\title{
Non-healing ulcer of right foot due to Monckeberg's arteriosclerosis
}

\author{
Rajaram Prasad, ${ }^{1}$ Tom Devasia, ${ }^{1}$ Hashir Kareem, ${ }^{1}$ Ashok Kumar ${ }^{2}$
}

${ }^{1}$ Department of Cardiology, Kasturba Medical College, Manipal, Karnataka, India ${ }^{2}$ Department of Medicine, Srinivas Institute of Medical Science, Mangalore, Karnataka, India

\section{Correspondence to} Dr Rajaram Prasad; prasad. asaithambi@gmail.com

Accepted 8 January 2015
CrossMark

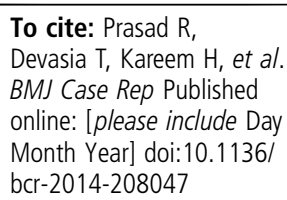

\section{DESCRIPTION}

A 55-year-old woman, a known hypertensive on treatment, was admitted with right lower limb claudication on walking up to $100 \mathrm{~m}$; there was pain on rest. She had an ulcer in the third interdigital space of the right foot for 3 months, which had not healed in spite of regular wound dressing. The patient denied history of trauma. On physical examination, her right lower limb was cold with absence of popliteal and distal pulses, and had a marked pallor at limb elevation. There was presence of an ulcer in the third interdigital space. The left lower limb was normal, with normal femoral pulse and absence of popliteal and distal pulses.

The patient's haemoglobin was $11.3 \mathrm{~g} / \mathrm{dL}$, total white cell count was $8600 / \mu \mathrm{L}$ with neutrophils $(63 \%)$, lymphocytes $(24 \%)$ and monocytes $(9 \%)$, and normal platelet count; she had an erythrocyte sedimentation rate of $55 \mathrm{~mm} / \mathrm{h}$; urea $19 \mathrm{mg} / \mathrm{dL}$ and creatinine $0.7 \mathrm{mg} / \mathrm{dL}$; she had $98 \mathrm{mg} / \mathrm{dL}$ random sugar; $159 \mathrm{mg} / \mathrm{dL}$ triglycerides; $129 \mathrm{mg} / \mathrm{dL}$ lowdensity lipoprotein; $31 \mathrm{mg} / \mathrm{dL}$ high-density lipoprotein; $192 \mathrm{mg} / \mathrm{dL}$ total cholesterol; rheumatoid factor, antinuclear antibodies, cryoglobulins and anticardiolipin antibodies IgM and IgG were negative, anticytoplasm antibody was also negative, serology for syphilis and serology for hepatitis B and $\mathrm{C}$ were negative. Serum calcium and phosphate levels were 8.5 and $3.5 \mathrm{mg} / \mathrm{dL}$. Parathyroid hormone was $71 \mathrm{pg} / \mathrm{mL}$. Vitamin D levels were normal.

Coronary angiogram was normal. Plain fluoroscopy showed significant calcification of bilateral superficial femoral, popliteal arteries with total occlusion of anterior, posterior and peroneal arteries (videos 1 and 2). Peripheral angiogram with contrast injection showed normal flow in common

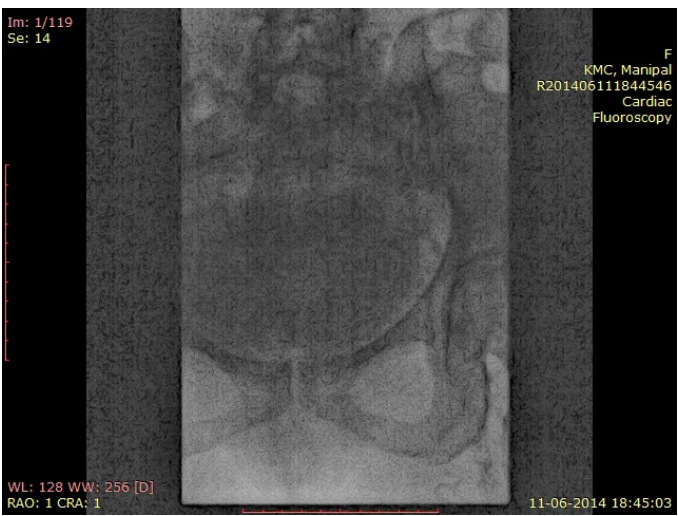

Video 1 Anteroposterior plain fluoroscopy view showing extensive calcification of the right superficial femoral and popliteal artery.

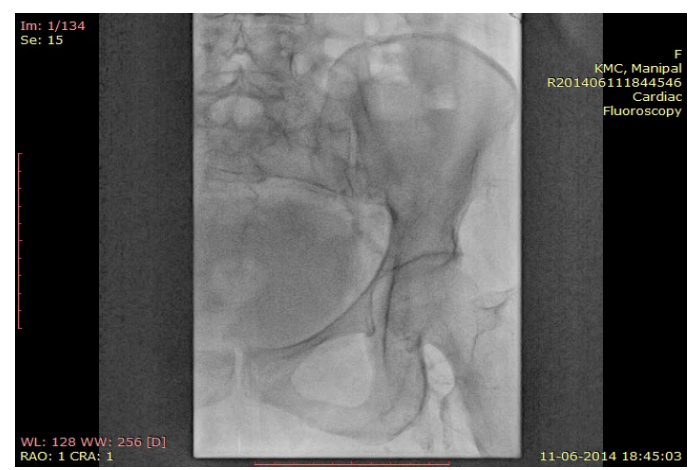

Video 2 Anteroposterior plain fluoroscopy view showing extensive calcification of the left superficial femoral and popliteal artery.

iliac, common femoral and proximal significant occlusion of the superficial femoral artery with extensive collaterals; flow in popliteal artery was noted with diffuse distal disease in right lower limb

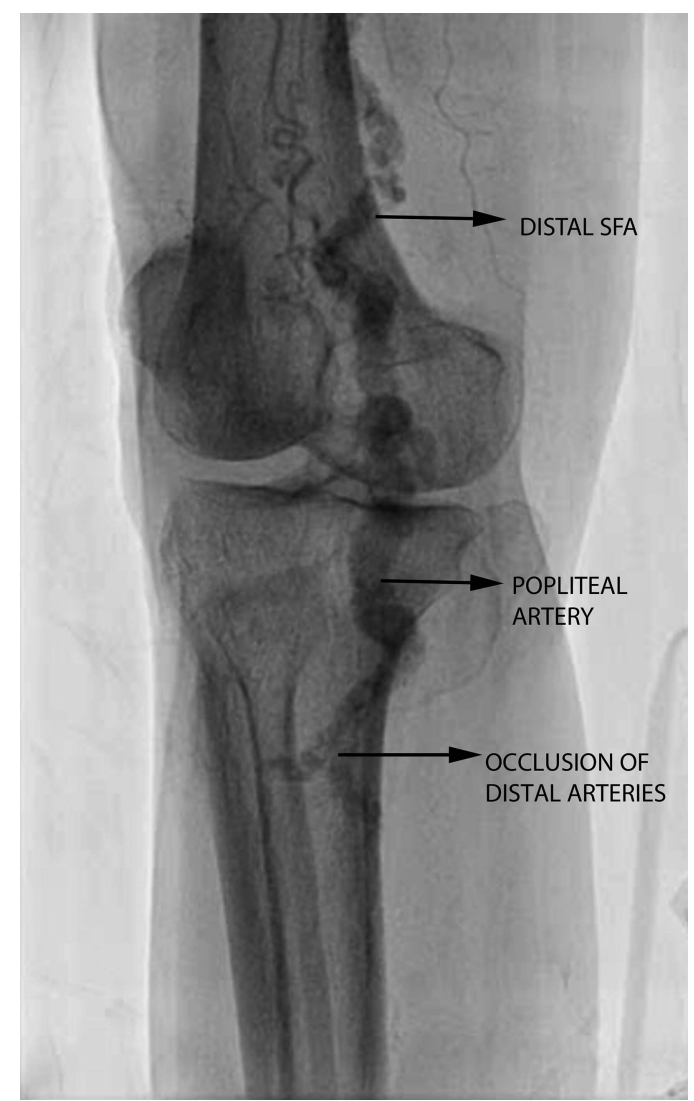

Figure 1 Anteroposterior view showing extensive calcification of the distal right superficial femoral (SFA) and popliteal artery and total occlusion of proximal anterior and posterior tibial artery. 


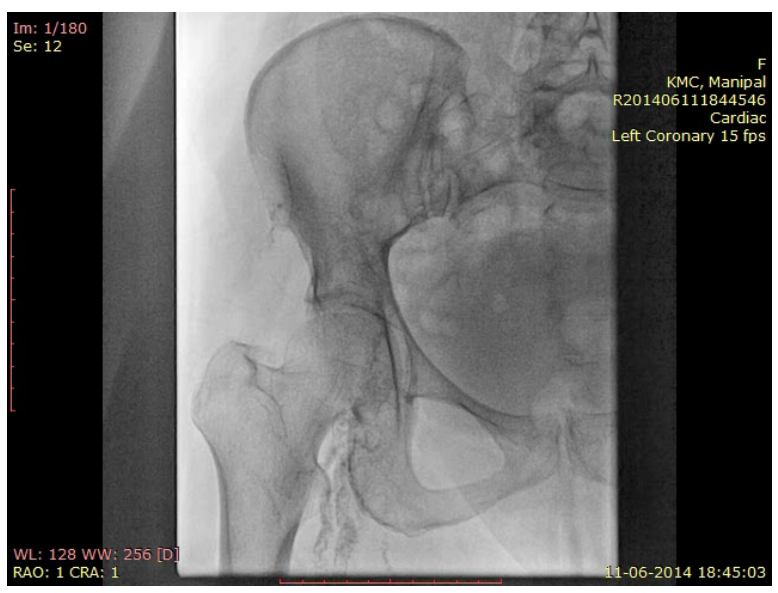

Video 3 Anteroposterior view showing extensive calcification and multiple stenosis of the right superficial femoral and total occlusion of popliteal artery distally.

(figure 1 and video 3 ) and left lower limb (figure 2 and video 4), which is clearly visualised by the failure of passage of contrast through the distal vessel. Multiple collaterals were noted at the proximal superficial femoral arteries (figure 2).

Monckeberg's sclerosis, also known as medial calcific sclerosis, is defined as the dystrophic calcification of tunica media of vessels due to deposition of hydroxyapatite crystals. Patients

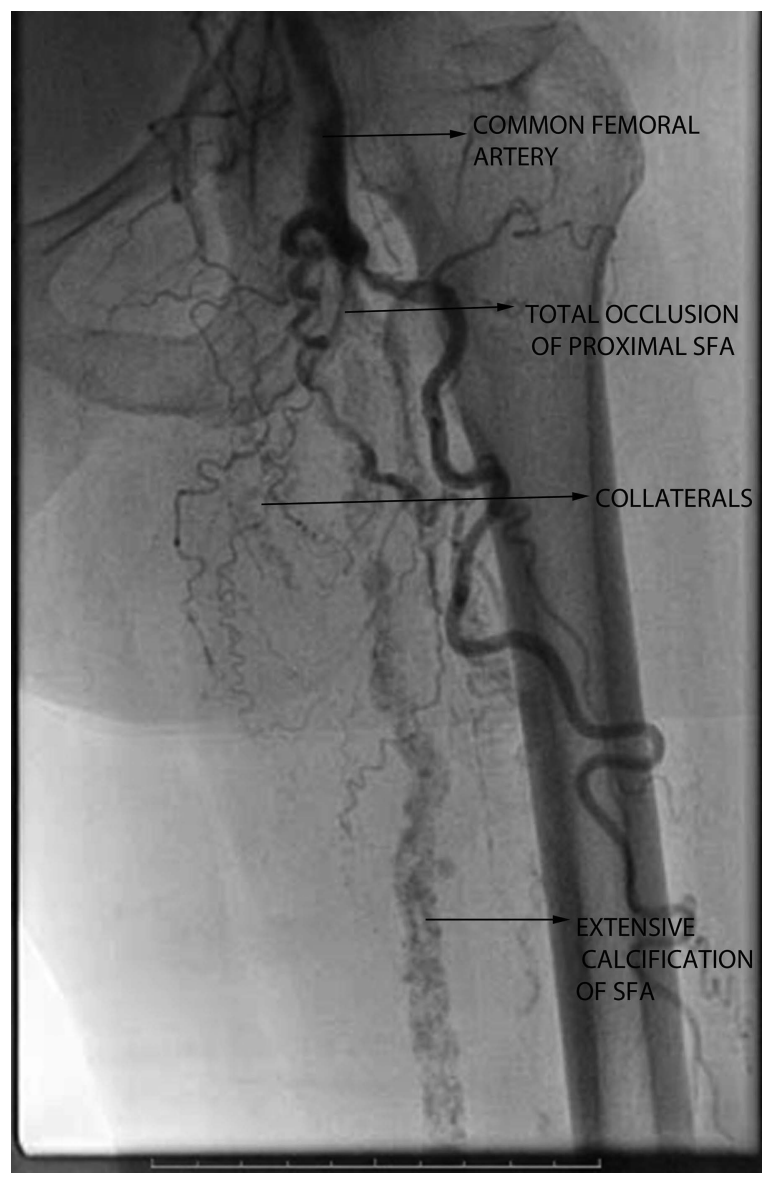

Figure 2 Anteroposterior view showing proximal occlusion of the left superficial femoral artery (SFA) with multiple collaterals and extensive calcification.

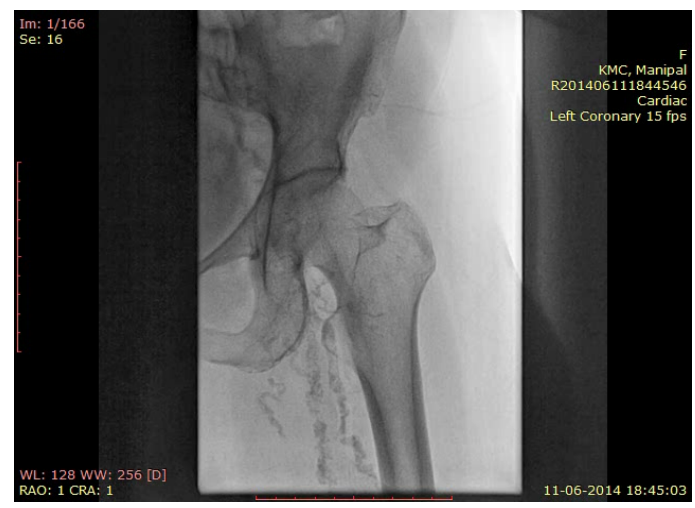

Video 4 Anteroposterior view showing extensive calcification of the distal left superficial femoral and total occlusion of popliteal artery distally.

with diabetes mellitus and chronic kidney disease are more prone to develop medial calcific sclerosis. Other risk factors include age, systemic lupus erythaematosus, chronic inflammatory conditions and hypervitaminosis D. The pericytes and smooth muscles of tunica media contain vesicles with hydroxyapatite. ${ }^{1}$ The disordered calcium phosphate regulation leads to release of calcium into the media and crystallised deposition of the calcium. The intima is rarely involved. The failure of inhibition of calcification is due to loss of expression of certain proteins such as osteoprotegerin, fibrillin I and carbonic anhydrase. $^{2}$

Clinically, patients are asymptomatic in the majority of these cases. But Monckeberg's sclerosis has been described as a risk factor for cardiovascular disease. ${ }^{3}$ It commonly involves peripheral and coronary arteries but involvement of aorta, visceral vessels and pharynx causing obstructive sleep apnoea have been described. ${ }^{4}$ In our patient, there was diffuse calcification of the lower limb arteries, leading to peripheral vascular disease with a non-healing ulcer in the right foot.

\section{Learning points}

- Monckeberg's sclerosis is the calcification of the tunica media due to dysregulation of calcium metabolism.

- Patients may be asymptomatic, but it can be an independent risk factor for cardiovascular morbidity and mortality.

Competing interests None.

Patient consent Obtained.

Provenance and peer review Not commissioned; externally peer reviewed.

\section{REFERENCES}

1 Micheletti RG, Fishbein GA, Currier JS, et al. Calcification of the internal elastic lamina of coronary arteries. Mod Pathol 2008;21:1019-28.

2 Shanahan CM, Cary NR, Salisbury JR, et al. Medial localization of mineralization-regulating proteins in association with Mönckeberg's sclerosis evidence for smooth muscle cell-mediated vascular calcification. Circulation 1999;100:2168-76.

3 Lehto S, Niskanen L, Suhonen M, et al. Medial artery calcification. A neglected harbinger of cardiovascular complications in non-insulin-dependent diabetes mellitus. Arterioscler Thromb Vasc Biol 1996;16:978-83.

4 Couri CE, da Silva GA, Martinez JA, et al. Mönckeberg's sclerosis-is the artery the only target of calcification? BMC Cardiovasc Disord 2005;5:34 
Copyright 2015 BMJ Publishing Group. All rights reserved. For permission to reuse any of this content visit http://group.bmj.com/group/rights-licensing/permissions.

BMJ Case Report Fellows may re-use this article for personal use and teaching without any further permission.

Become a Fellow of BMJ Case Reports today and you can:

- Submit as many cases as you like

- Enjoy fast sympathetic peer review and rapid publication of accepted articles

- Access all the published articles

- Re-use any of the published material for personal use and teaching without further permission

For information on Institutional Fellowships contact consortiasales@bmjgroup.com

Visit casereports.bmj.com for more articles like this and to become a Fellow 